\author{
I. Mincheva, A. Petrova, M. Yordanova \& E. Kozuharova
}

\title{
Is the traditional use of "salep" in the Bulgarian Rhodopes hazardous for the wild populations of terrestrial orchids?
}

\begin{abstract}
Mincheva, I., Petrova, A., Yordanova, M. \& Kozuharova, E.: Is the traditional use of "salep" in the Bulgarian Rhodopes hazardous for the wild populations of terrestrial orchids? - Fl. Medit. 28: 399-418. 2018. - ISSN: 1120-4052 printed, 2240-4538 online.

In Bulgaria and the eastern Mediterranean, dried tubers of terrestrial orchids are known as "salep", which also refers to ground tuber powder and the beverage made from this powder. Collection of "salep" from wild populations was shown to be hazardous factor for the native populations. In this preliminary study we investigate how popular "salep" is in the Bulgarian Rhodopes and to what extent it is collected and utilized. Distribution maps were constructed based on personal data, data from Herbaria, and publications from the Bulgarian part of the Rhodopes. During 2014 and 2015 we performed semi-structured interviews in different locations in the Rhodopes in order to evaluate the popularity, use and collection of "salep". The initial data obtained from the interviews indicate that "salep" is not popular amongst the local people in the Rhodopes and especially Central Rhodopes. Most informants responded that "they have never heard of "salep". Some informants responded that they know the name but details about use are blurring. For the moment the local human activity does not threaten the wild orchid populations, but permanent monitoring in necessary.
\end{abstract}

Key words: Orchidaceae, Rhodopes Mts, conservation, distribution, Bulgaria.

\section{Introduction}

The common name of genus Orchis in Bulgaria is "salep" (Stojanov 1964). In Bulgaria and the eastern Mediterranean, dried tubers of terrestrial orchids are known as "salep", which also refers to ground tuber powder and the beverage made from this powder (Kasparek \& Grimm 1999; Kreziou \& al 2016). In Turkey, "salep" is used in icecream production (dundurma), confectionery and beverages. Turkish "salep" is produced from wild orchids. The "bulbs" are collected by villagers when the plants are in flower and it is easy to locate them. The whole plant is dug out together with its tubers. The wrinkled brown mother tubers, source of the blooming orchid is thrown away. The swollen daughter tuber grown to produce new tubers is boiled in order to prevent the sprouting and processed for "salep" production (Kasparek \& Grimm 1999). "Salep" is derived from at least 30 species from the genera Aceras, Anacamptis, Barlia, Dactylorhiza, 
Himantoglossum, Ophrys, Orchis, and Serapias (Kasparek \& Grimm 1999; Sezik 2002; Ertug 2004; Tamer \& al. 2006; Ghorbani 2014a, 2014b). By the year 1999 it is estimated that about 10-20 million orchid tubers are collected annually in Turkey which is a signal for threatening of the wild populations (Kasparek \& Grimm 1999). The amount of annual export in eighteenth century was evaluated to 6.5 tons (Ari \& al. 2005). Most of the species exported before are now within endangered plant classes. Even though the CITES forbids or restricts international commercial trade of wild orchids and despite all the laws that have been put into effect, the pulling of these wild "salep"orchids has been continued since 1974 for interior trade. "Salep" orchids, Orchis sp. div. are amongst the merchandised medical and aromatic herbs used in Turkey. The legislation regulations are not enough effective for protection (Tecimen \& al. 2010; Akbulut Bayramoglu 2013; de Boer \& al. 2017; Molnár \& al. 2017). Even though "salep" is not commonly consumed in Iran, the current orchid collection boom in that country is driven by international demand, particularly from Turkey, Pakistan and India, and the resultant high prices. This is a hazardous factor for the native populations (Ghorbani 2014a, 2014b; de Boer \& al. 2017). This is a signal that monitoring of the harvesting and trade should be performed even in countries where wild orchids are not traditionally harvested as "salep" and used in traditional medicine and for food. After the tubers and rhizomes are collected it is impossible to identify the species and therefore various molecular techniques have gained widespread use as an important tool associated with the preservation and identification of endangered plant resources (Ari \& al. 2005; Ghorbani 2014).

Traditional use of "salep" and harvesting from the wild populations in the mountains of Greece and Albania is a hazard for the native populations of some orchids. Selected species in the genera Anacamptis, Dactylorhiza and Orchis were found to be used for the production of "salep" in Greece at present time (Kreziou \& al. 2016).

In Bulgaria, salep used to be collected historically (Stojanov \& Kitanov 1960). The collecting steadily had declined during the last decades of the past century (Mitrev \& al. 1978; Hardalova \& al. 1994). The collecting, buying up and trade of "salep" were forbidden at 1995. In the area of the study, Vassileva (Vassileva \& Vichotsevskyi 1974; Vassileva pers. commun, 1998) registered extreme decline of a population of rare Orchis provincialis near Chakalarovo village in Eastern Rhodopes due to collecting for salep from a single herbalist. Nowadays, according to the Medicinal Plant Act (2000) in Bulgaria 19 species of the family that are considered medicinal but their collecting is forbidden. The taxa under protection of the Biological Diversity Act $(2000,2007)$ are 30 . In this preliminary study we investigate how popular "salep" is in the Bulgarian Rhodopes and to what extent it is collected and utilized.

\section{Material and methods}

\section{Distribution of some orchids in the Rhodopes}

Potentially all species from the genera Anacamptis, Dactylorhiza, Gymnadenia, Himantoglossum, Neotinea, Ophrys, Orchis, Platanthera, Serapias could be used for "salep", even though many of these taxa make small populations with sporadically occurring individuals, which is not convenient for mass collection. We focused on some orchids 
of potential importance for production of "salep" namely the genera Anacamptis Dactylorhiza, Neotinea and Orchis. We chose these genera because they were found to be used for the production of "salep" in North Greece at present time - nearest area to the Rhodopes by Kreziou and co authors (Kreziou \& al. 2016). From these genera we selected 24 taxa for this investigation because they are distributed in the Rhodopes (Table 1, nomenclature mainly after Euro+Med (2006-2017). Despite our concerns about the taxonomical problems in the group Dactylorhiza cordigeta, D. baumanniana and D. pindica we included the first two in this research and built distribution maps considering the fact that they occur in the studied area and might be used as is in Greece.

The distribution maps were constructed based on personal observations of the authors in the Bulgarian part of the Rhodopes; data from the Personal Database on the distribution of Orchidaceae species in Bulgaria of Petrova, A., Venkova, D. \& Gerasimova, I. (containing personal data as well as data from Bulgarian Herbaria SO, SOM SOA and 6 internationally not registered herbaria of regional Natural history museums), and publications focused on orchids in Rhodopes Mts (Gerasimova \& al. 1998; Petrova \& al. 2001; Gerasimova \& al. 2003, Petrova 2004; Trifonov 2005; Petrova \& Assyov 2008).

The conservation status of the species is based on Bulgarian legislation acts and Red List of Bulgarian Vascular Plants (Petrova \& Vladimirov 2009).

\section{Ethnobotany data collection}

Study sites. The present study is part of a larger ethnobotanical survey carried out in different localities of Rhodopes Mountains during June 2014 and September 2015. We selected study sites in 30 villages both in Central and East Rhodopes (Fig. 1).

Ethnobotanical evaluation. Semi-structured interviews were held among 76 persons (42 women and 34 men, at average age of 60, range 30-80) in different locations in the Central Rhodopes and 105 persons (59 women and 46 men, at average age of 60, range 30-80) persons from the East Rhodopes. Informants were asked: 1) do they know what is salep" and what is it used for; 2) do they use/collect themselves "salep"; 3) do they know someone else to use and collect "salep" for home use; 4) are they aware for orchids trade connected with "salep" production.

Data analysis. Ethnobotanical data were analyzed and summarized by using Microsoft excel and statistics to determine relative frequencies of citations. Data from the audio records of the interviews were transformed in Microsoft excel tables. Descriptive statistics was used to analyze the data obtained.

\section{Result and discussion}

\section{Distribution of some orchids in the Rhodopes}

More than $85 \%$ of the orchid species recorded for Bulgarian flora are presented in the Rhodopes (Assyov \& al. 2012; Yordanova 2016). The list of the selected species of the genera Anacamptis, Dactylorhiza, Neotinea and Orchis is presented in Table 1. The known distribution of the studied species is presented on Maps (Electronic Suplementary File 1). It is quite uneven. This is in some degree result of unevenly distributed botanical studies and those of the orchids over the area. Rich of taxa regions are those with lime- 


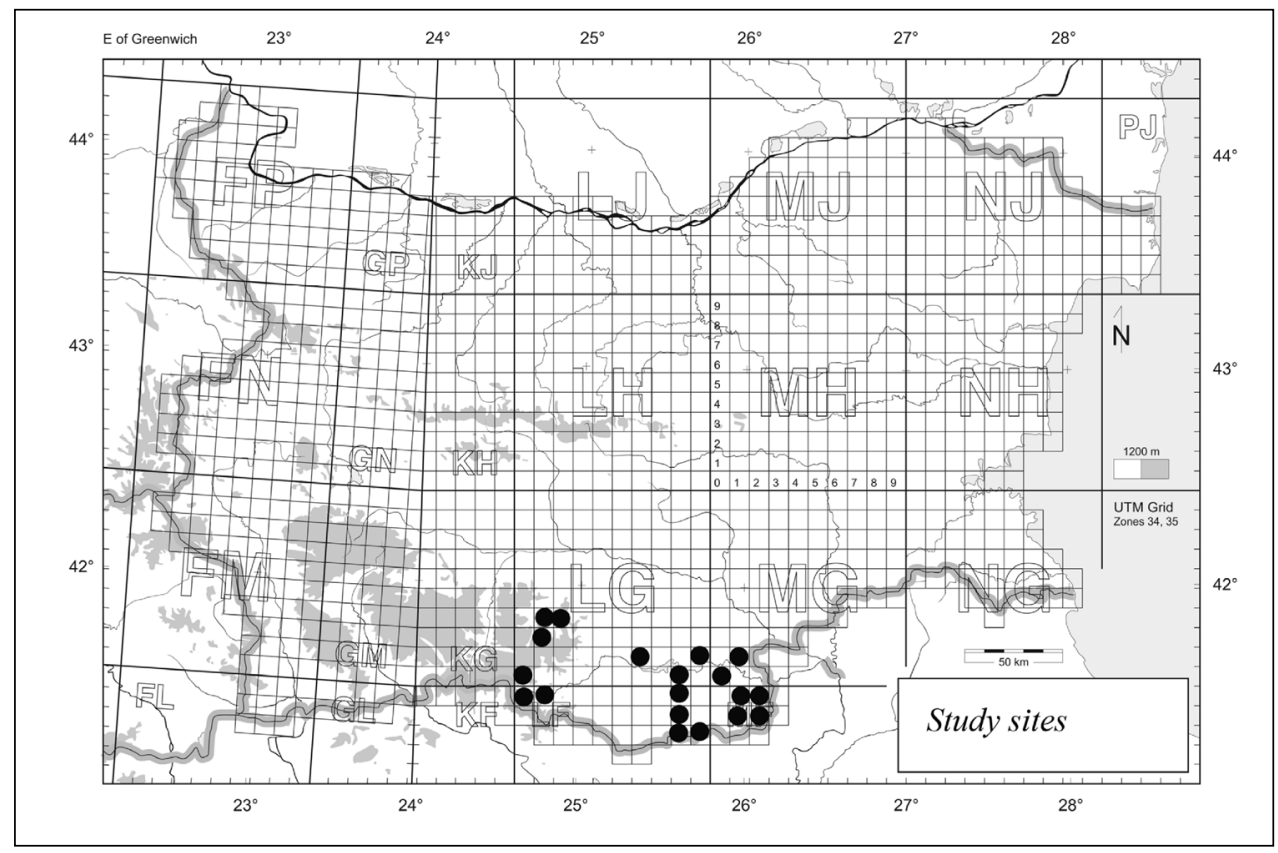

Fig. 1. Study sites in the Bulgarian Rhodopes Mountains.

stone terrain: Smolyan-Trigrad area and Dobrostan massiv south of Assenovgrad in the Central Rhodopes and Ivailovgrad area in the Eastern Rhodopes. Despite the fact that the mountains are characterized by high orchid species richness, our observations are that populations of most of the taxa are not numerous, and often in localities are presented by sporadic individuals. Species with numerous populations are mostly those of genus Anacamptis: A. laxiflora, A. morio, A. papilionaceae, A. pyramidalis as well as Dactylorhiza cordigera, and D. sambucina. Extremely rare with single populations are Dactylorhiza kalopissii and Orchis spitzelii.

Repeated observations during the last 2 decades showed considerable changes of the local distribution and the state of many populations. Factors with a negative impact are: abandonment of former meadows and pastures and their overgrowing with shrubs, especially in remote areas; destroying of wet and mesic grasslands because of resort' development in Pamporovo, Chepelare, Tsigov Chark and other areas; building of mini water power station - Orchis militaris and Orchis spitzelii were not reconfirmed in the area of Trigrad-Chairite (KG81) after such construction works.

\section{Ethnobotany data collection}

Many informants responded that they have never heard of "salep" especially in Central Rhodopes Mts. (Table 2). In the Central Rhodopes Mts. the informants who responded that they know the name, mainly new the application as a beverage $(80.9 \%)$. There were several reports for "salep" as medicinal plant, but the informants 
Table 1. Orchids that might be used for „salep” production which we selected as object of this investigation distributed in the Rhodopes Mts.

\begin{tabular}{|c|c|c|c|c|}
\hline Taxon & $\begin{array}{c}\text { Orchids } \\
\text { recognized as } \\
\text { medicinal } \\
\text { plants } \\
\text { Medicinal } \\
\text { Plants Act } \\
2000\end{array}$ & $\begin{array}{c}\text { Orchids } \\
\text { protected by } \\
\text { Biological } \\
\text { Diversity Act } \\
2002,2007\end{array}$ & CITES & $\begin{array}{l}\text { Orchids listed } \\
\text { in the } \\
\text { Bulgarian } \\
\text { Red Data List }\end{array}$ \\
\hline $\begin{array}{l}\text { Anacamptis coriophora (L.) R. M. Bateman, } \\
\text { Pridgeon \& M. W. Chase }\end{array}$ & + & + & + & \\
\hline $\begin{array}{l}\text { Anacamptis laxiflora }(\text { Lam }) \text { M. Bateman, } \\
\text { Pridgeon \& M. W. Chase }\end{array}$ & + & + & + & VU \\
\hline $\begin{array}{l}\text { Anacamptis morio (L.) R.M. Bateman, Pridgeon } \\
\text { \& M.W.Chase. }\end{array}$ & + & & + & \\
\hline $\begin{array}{l}\text { Anacamptis palustris subsp. elegans (Heuff.) R. } \\
\text { M. Bateman, Pridgeon \& M. W. Chase }\end{array}$ & & & + & \\
\hline $\begin{array}{l}\text { Anacamptis papilionacea (L.) R. M. Bateman, } \\
\text { Pridgeon \& M. W. Chase }\end{array}$ & + & + & + & VU \\
\hline Anacamptis pyramidalis (L.) Rich. & & & + & VU \\
\hline $\begin{array}{l}\text { Neotinea tridentata (Scop.) R.M. Bateman, } \\
\text { Pridgeon \& M.W. Chase. }\end{array}$ & + & & + & \\
\hline $\begin{array}{l}\text { Neotinea ustulata (L.) R.M.Bateman, Pridgeon \& } \\
\text { M.W.Chase. }\end{array}$ & + & & + & $\mathrm{VU}$ \\
\hline Orchis pallens $\mathrm{L}$ & + & & + & \\
\hline Orchis mascula (L.) L. subsp. mascula s. 1. & + & & + & \\
\hline Orchis mascula subsp. speciosa (Mutel) Hegi & & & + & \\
\hline Orchis militaris $\mathrm{L}$. & + & + & + & $\mathrm{EN}$ \\
\hline Orchis provincialis Lam. \& DC. & + & + & + & CR \\
\hline Orchis purpurea Huds. & + & & + & \\
\hline Orchis simia Lam. & + & & + & \\
\hline Orchis spitzelii W. D. J. Koch & + & + & + & CR \\
\hline $\begin{array}{l}\text { Dactylorhiza baumanniana J. Hölzinger \& } \\
\text { Künkele }\end{array}$ & & & + & \\
\hline Dactylorhiza cordigera (Fr.) Soó & & & + & \\
\hline Dactylorhiza incarnata (L.) Soó, & & + & + & $\mathrm{EN}$ \\
\hline Dactylorhiza romana (Sebast.) Soó & & & + & VU \\
\hline Dactylorhiza kalopissii E.Nelson & & + & + & CR \\
\hline Dactylorhiza saccifera (Brongn.) Soó & & & + & \\
\hline Dactylorhiza sambucina (L.) Soó, & & & + & \\
\hline $\begin{array}{l}\text { Himantoglossum jankae Somlyay, Kreutz \& } \\
\text { Óvári }\end{array}$ & + & + & + & VU \\
\hline
\end{tabular}

(14.3\%) did not know particular application. Only one of all reports $(4.8 \%)$ was for application against kidney problems. In the East Rhodopes Mts. the informants who responded that they know the name, knew the application as a beverage $(100 \%)$. Persons who knew about its use got the information years ago from herb collectors or grandparents. The "salep popularity" is higher in East Rhodopes compared to the 
Table 2. Informant reports.

\begin{tabular}{|l|c|c|}
\hline & $\begin{array}{c}\text { Central Rhodopes Mts. } \\
\text { Percent of reports }\end{array}$ & $\begin{array}{c}\text { East Rhodopes Mts. } \\
\text { Percent of reports }\end{array}$ \\
\hline Do not know what is ,salep” & $73.7 \%$ & $24.8 \%$ \\
\hline Know what is ,salep” & $26.3 \%$ & $75.2 \%$ \\
\hline Collect tubers for home use & $1.3 \%$ & $1.0 \%$ \\
\hline Collect tubers of orchids to sell it & $0 \%$ & $0 \%$ \\
\hline $\begin{array}{l}\text { Know someone buys tubers of } \\
\text { orchids but the informant do not } \\
\text { collect personally }\end{array}$ & $1.3 \%$ & \\
\hline
\end{tabular}

Central Rhodopes (Table 2) but yet nowadays it is practically not used and collected. One of our informants reported that in the area of Madjarovo (East Rhodopes) no human destruction is detected. He observes the populations of orchids every flowering season. He only noted that the goats eat the flowers of Orchis mascula s. 1. but they never touch the flowers of Anacamptis pyramidalis. Additionally he reported that "salep" used to be a traditional drink in the village of Mandrica (inhabited by ethnic Albanians) and it was sold by special persons. Nowadays even though the traditions in the village in other human activities are still alive no one collects and uses "salep".

One informant reported collection for trade purpose with market outside of Bulgaria from some company located in town of Yambol, which is outside of the territory of studied area. Collection for trading purpose of all Orchis species in Bulgaria is forbidden for more than a decade according to the Medicinal plant act Promulgated, State Gazette No. 29/7.04.2000. The fact that despite the restrictions of low some illegal trade is mentioned indicates that the problem is of potential of importance and should not be neglected.

\section{Conclusions}

The initial data obtained from the interviews indicate that "salep" is not popular amongst the local people in the Rhodopes and especially in the Central Rhodopes. For the moment the local human activity does not threaten the wild orchid populations by collecting "salep". However monitoring is necessary in order to detect increased collection activity on time in order to prevent damages, because the populations of the orchids in the Rhodopes are usually consisted of small numbers of individuals and therefore are vulnerable. 


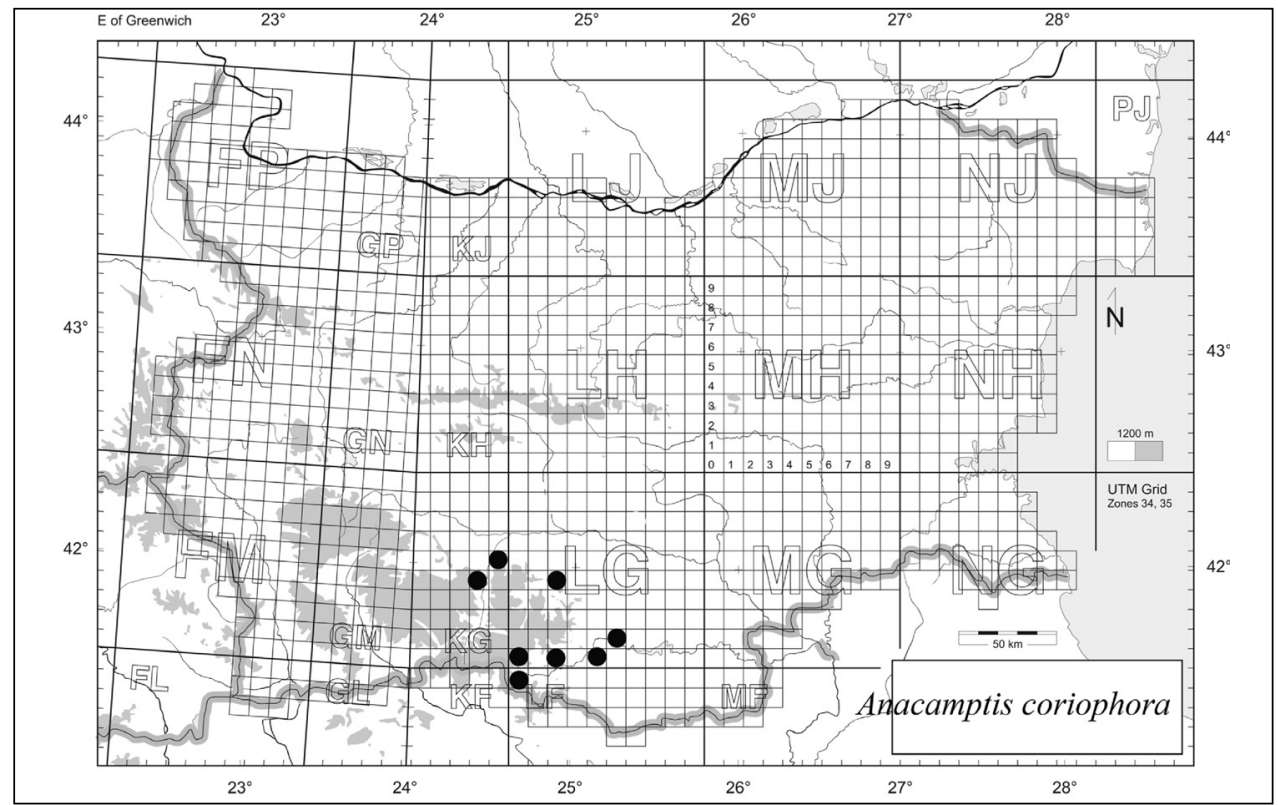

Fig. 2. Distribution of Anacamptis coriophora (L.) R.M. Bateman, Pridgeon \& M.W. Chase (= Orchis coriophora L.).

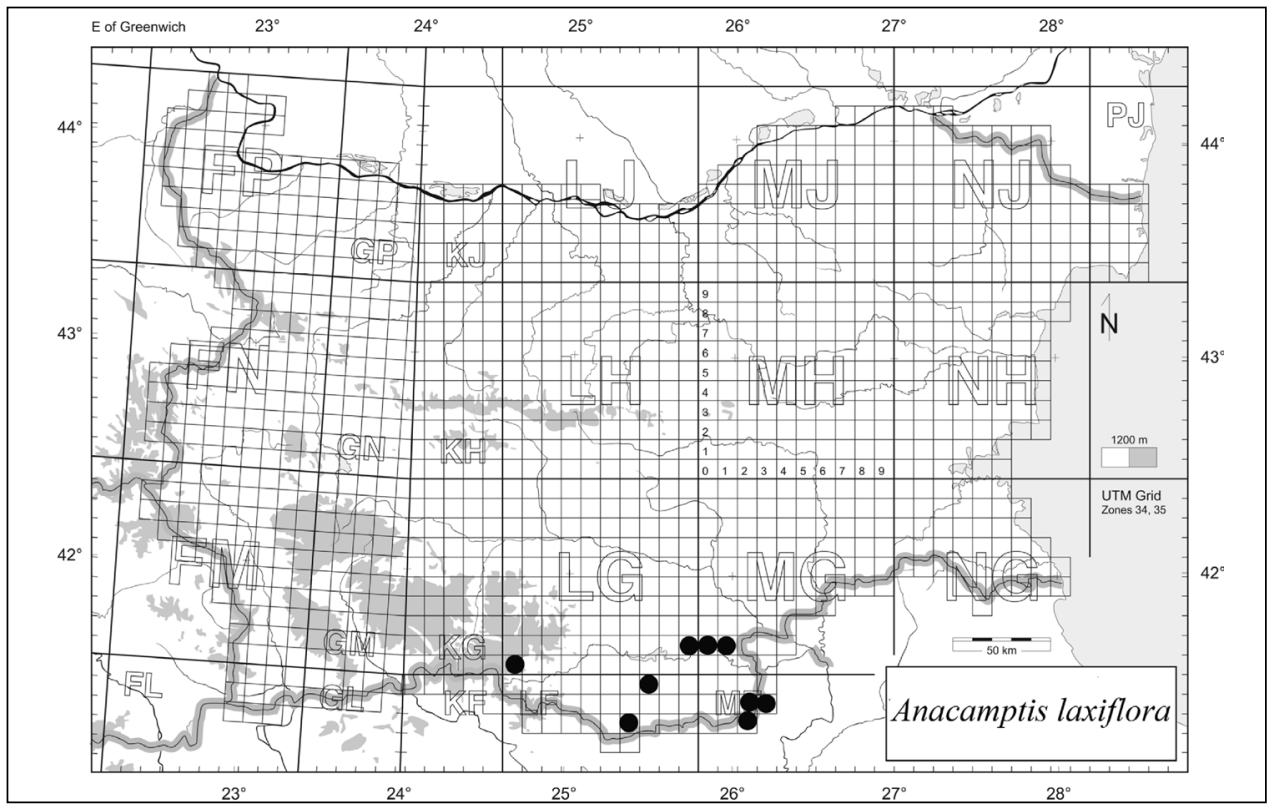

Fig. 3. Distribution of Anacamptis laxiflora (Lam) M. Bateman, Pridgeon \& M.W. Chase (= Orchis laxiflora C. A. Mey.). 


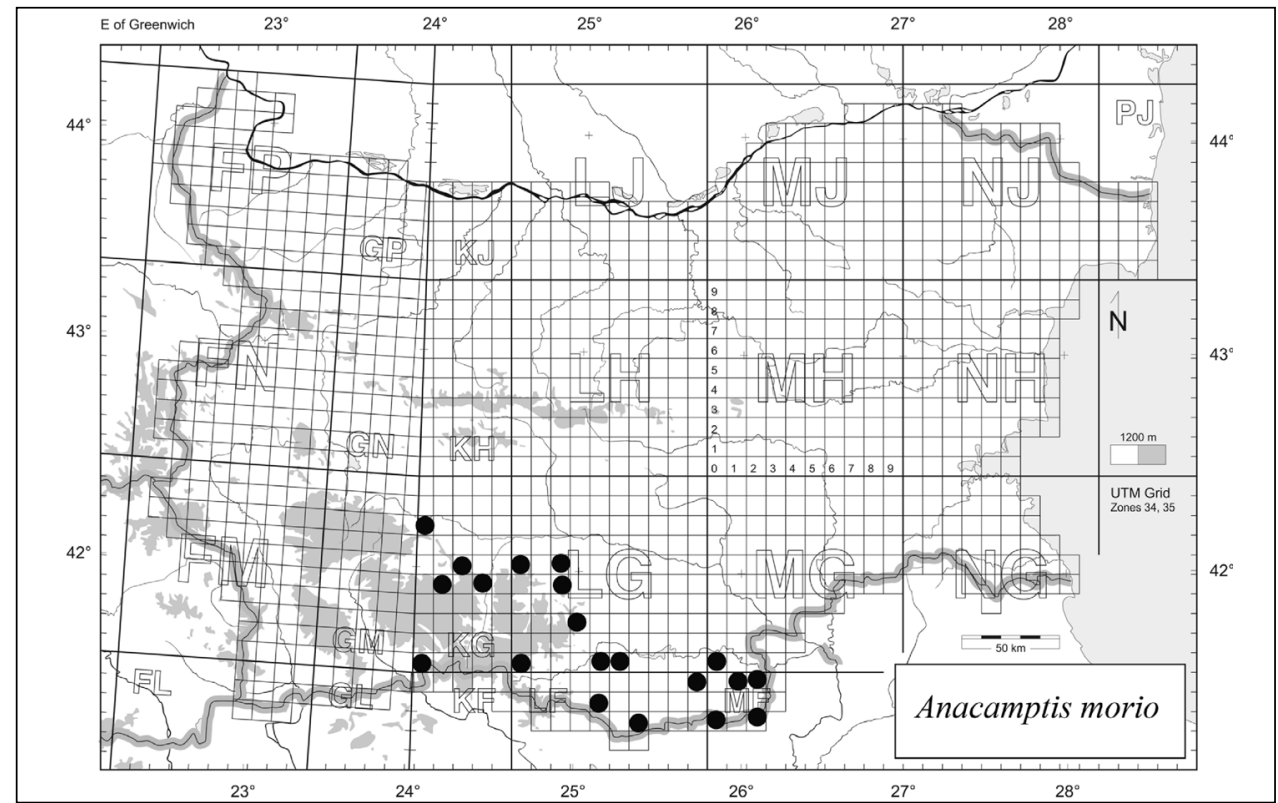

Fig. 4. Distribution of Anacamptis morio (L.) R.M. Bateman, Pridgeon \& M.W. Chase. (= Orchis morio L.).

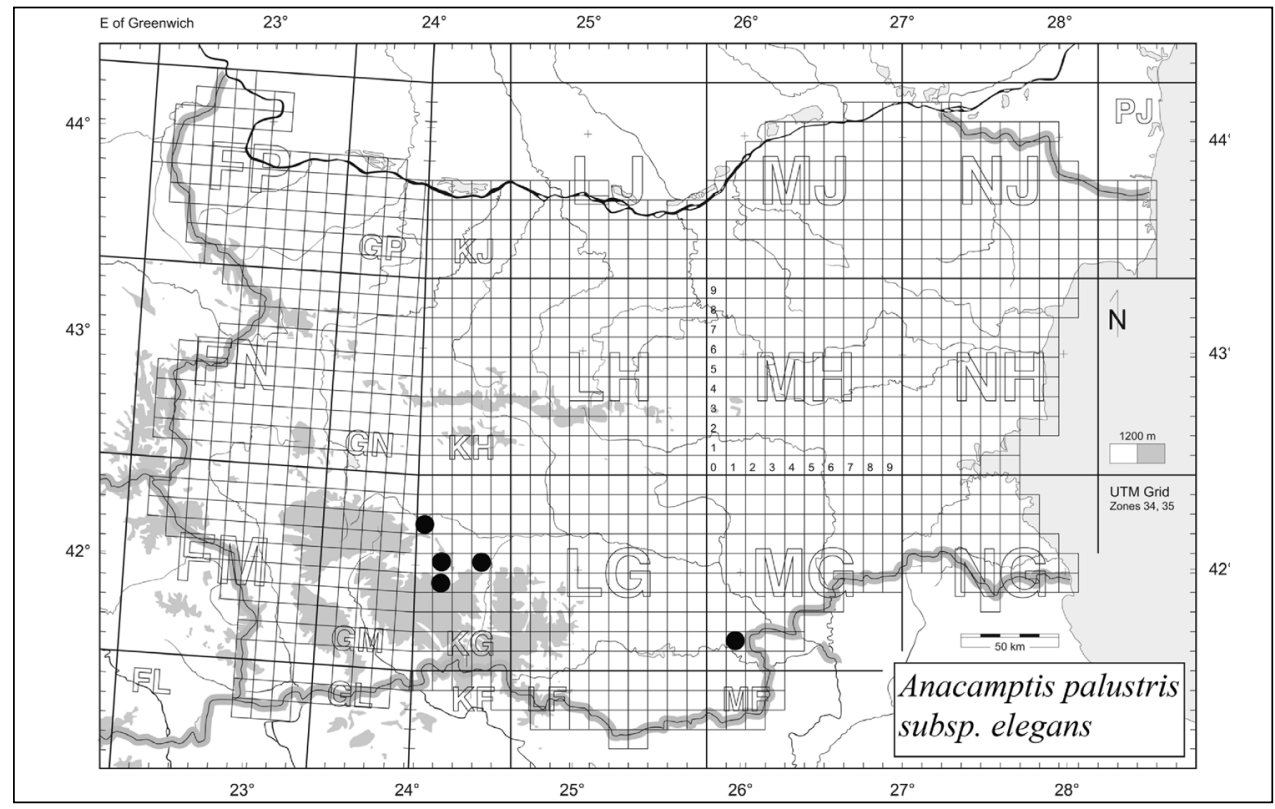

Fig. 5. Distribution of Anacamptis palustris subsp. elegans (Heuff.) R.M. Bateman, Pridgeon \& M. W. Chase (= Orchis elegans Heuff.). 


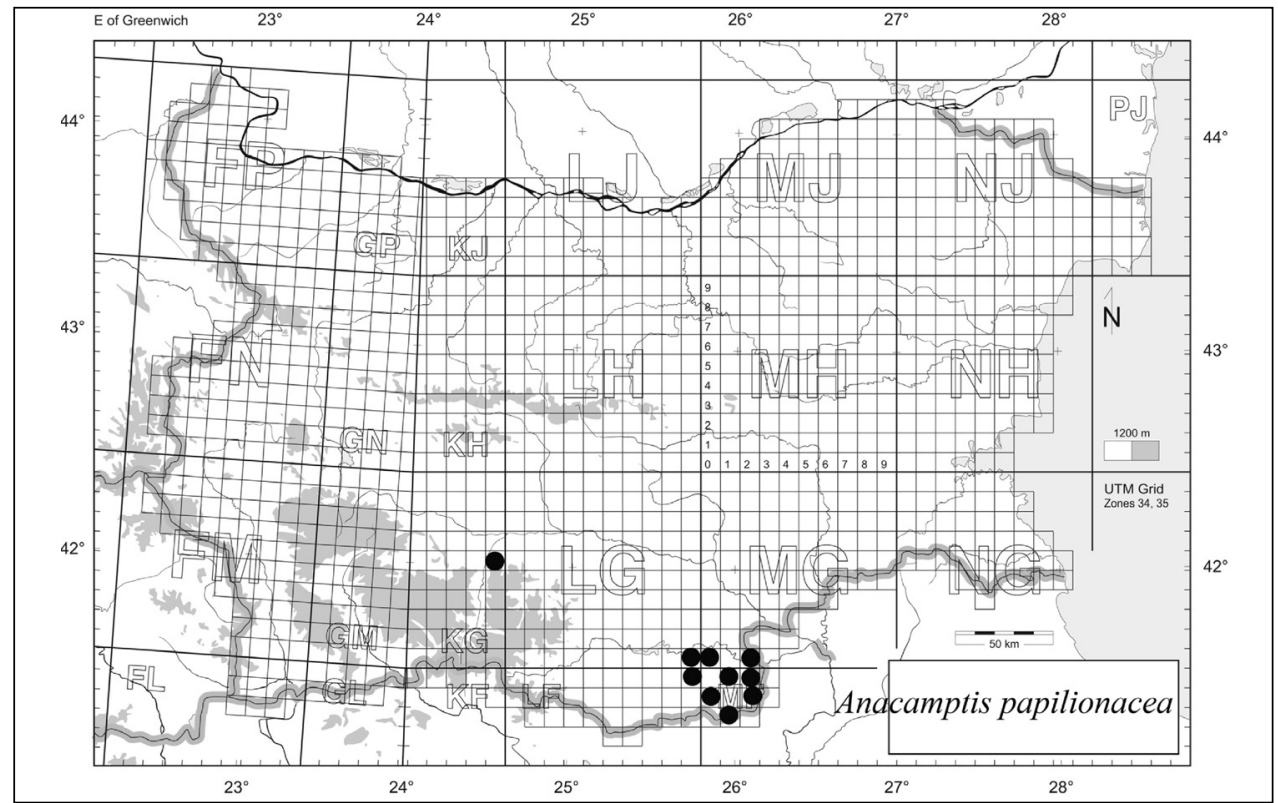

Fig. 6. Distribution of Anacamptis papilionacea (L.) R.M. Bateman, Pridgeon \& M.W. Chase (= Orchis papilionacea L.).

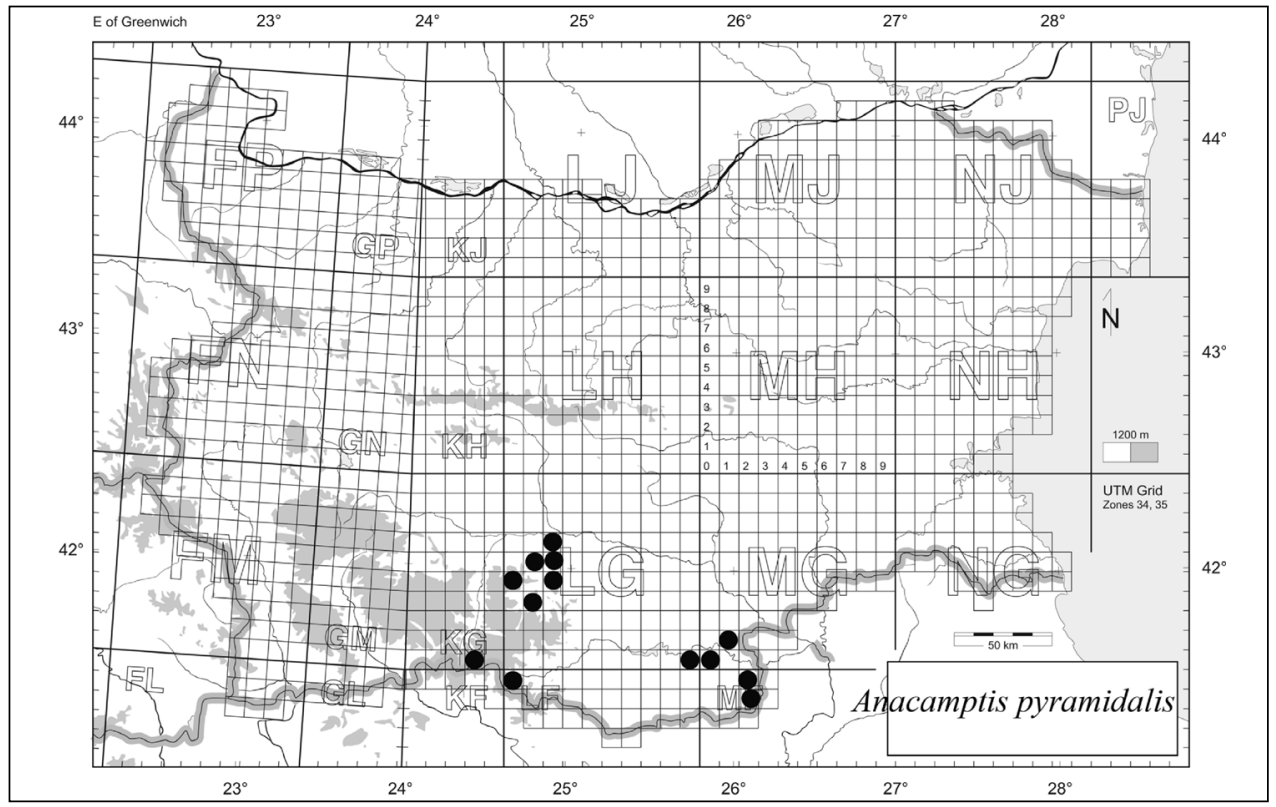

Fig. 7. Distribution of Anacamptis pyramidalis (L.) Rich. 


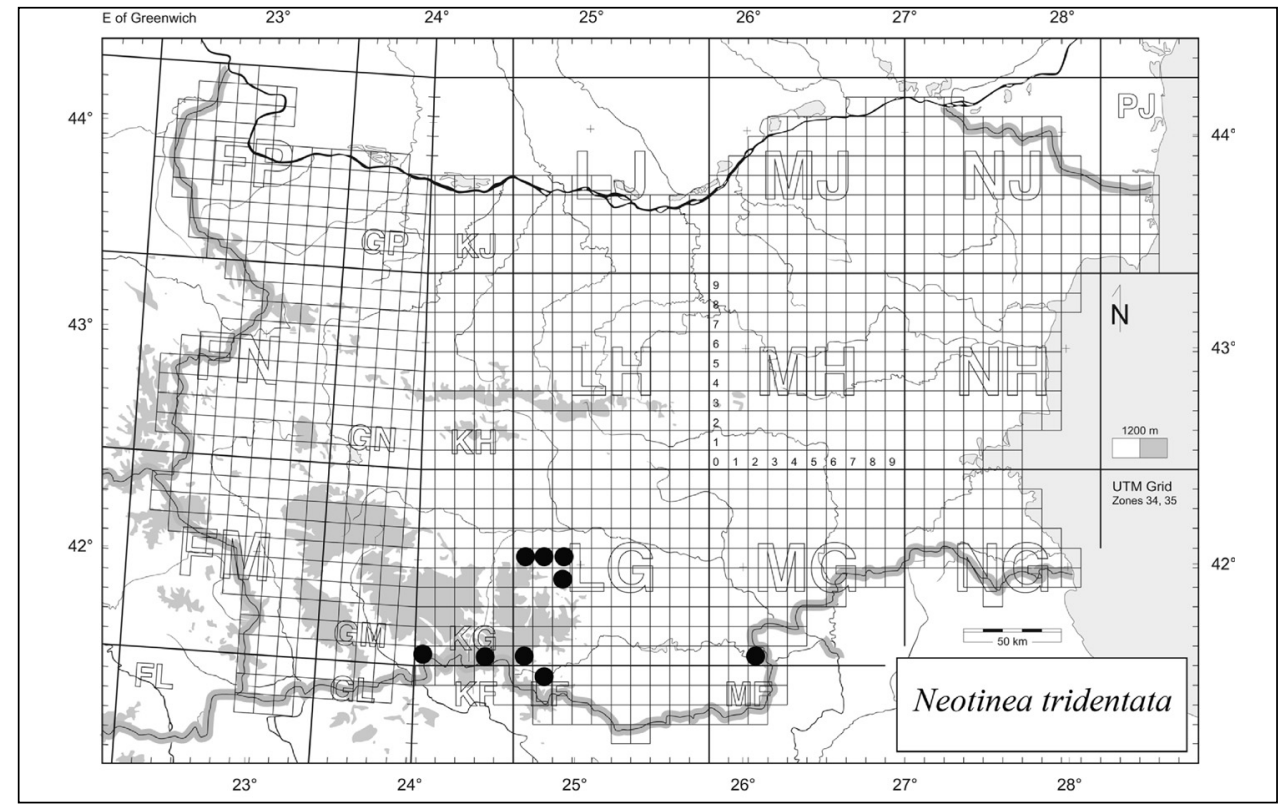

Fig. 8. Distribution of Neotinea tridentata (Scop.) R.M. Bateman, Pridgeon \& M.W. Chase. (= Orchis tridentata Scop.).

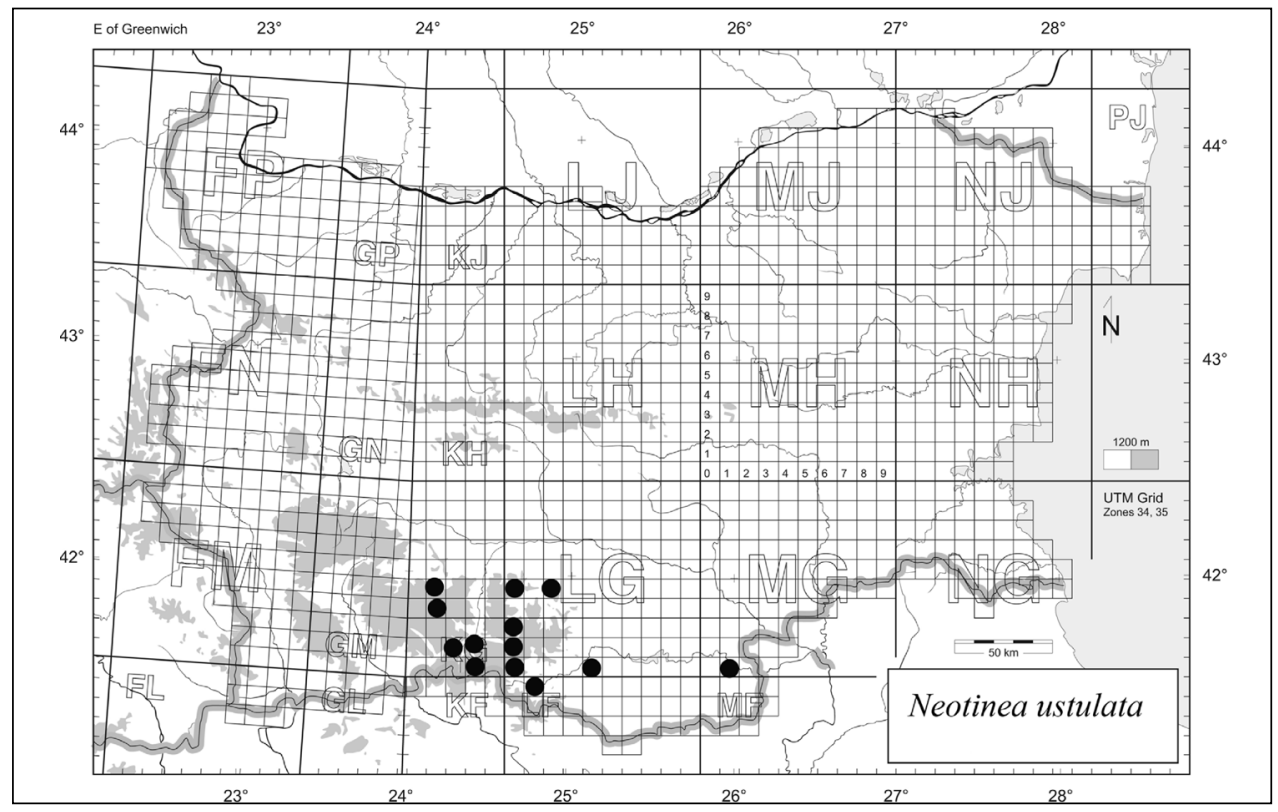

Fig. 9. Distribution of Neotinea ustulata (L.) R.M. Bateman, Pridgeon \& M.W. Chase. (= Orchis ustulata L.). 


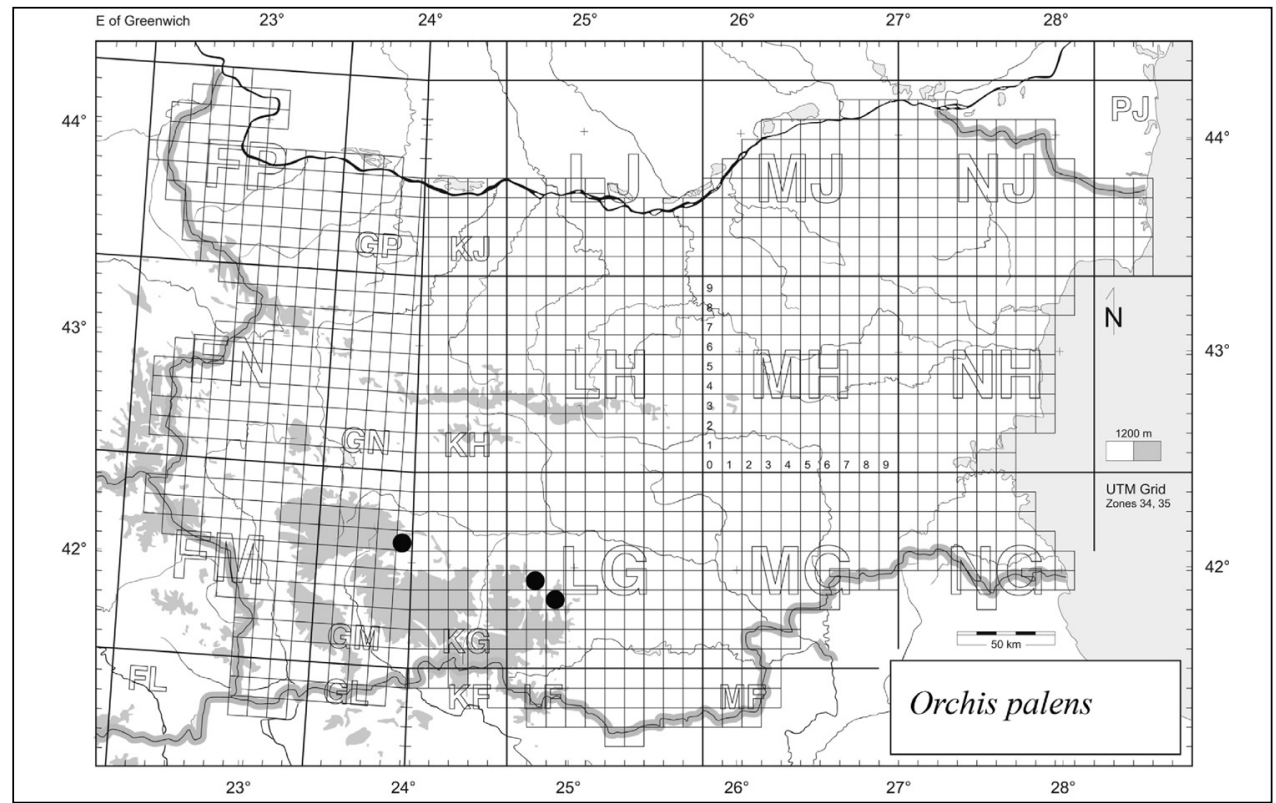

Fig. 10. Distribution of Orchis pallens L.

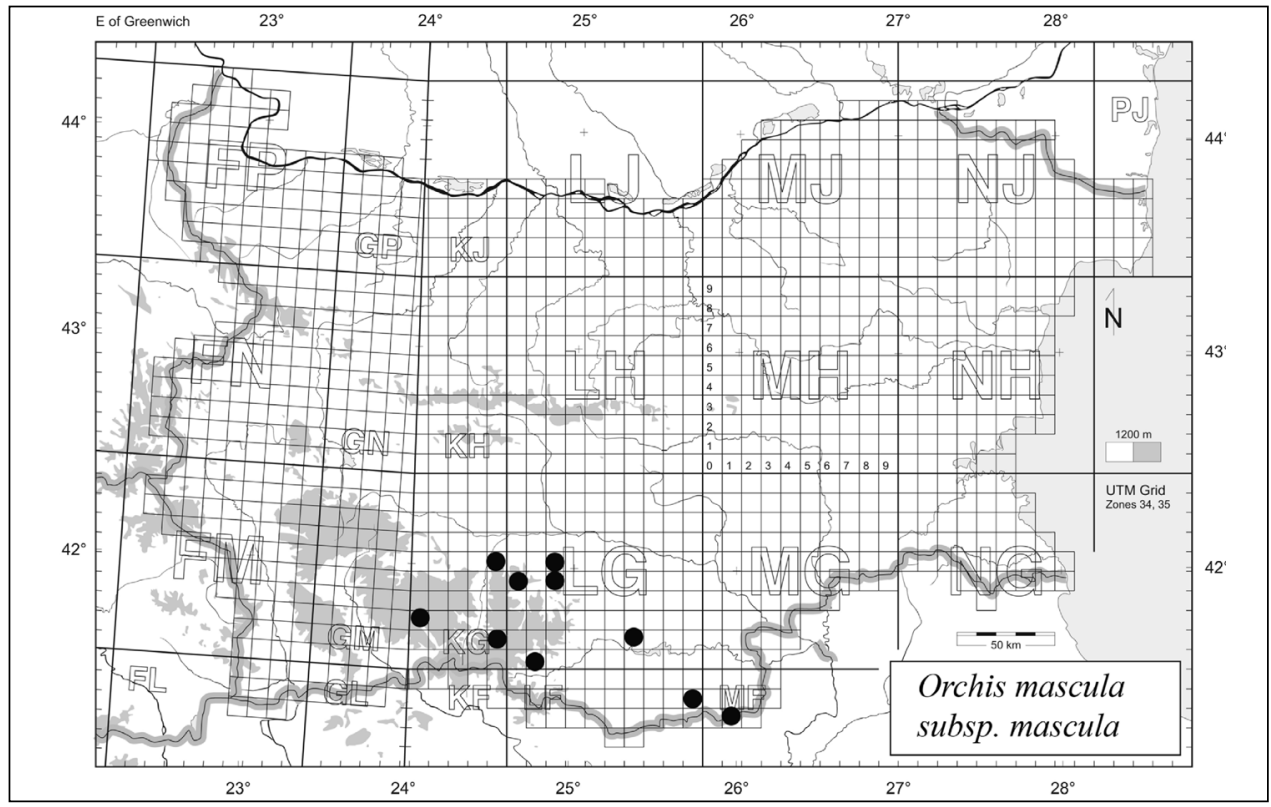

Fig. 11. Distribution of Orchis mascula (L.) L. subsp. mascula s. 1. (= Orchis pinetorum Boiss. \& Kotschy). 


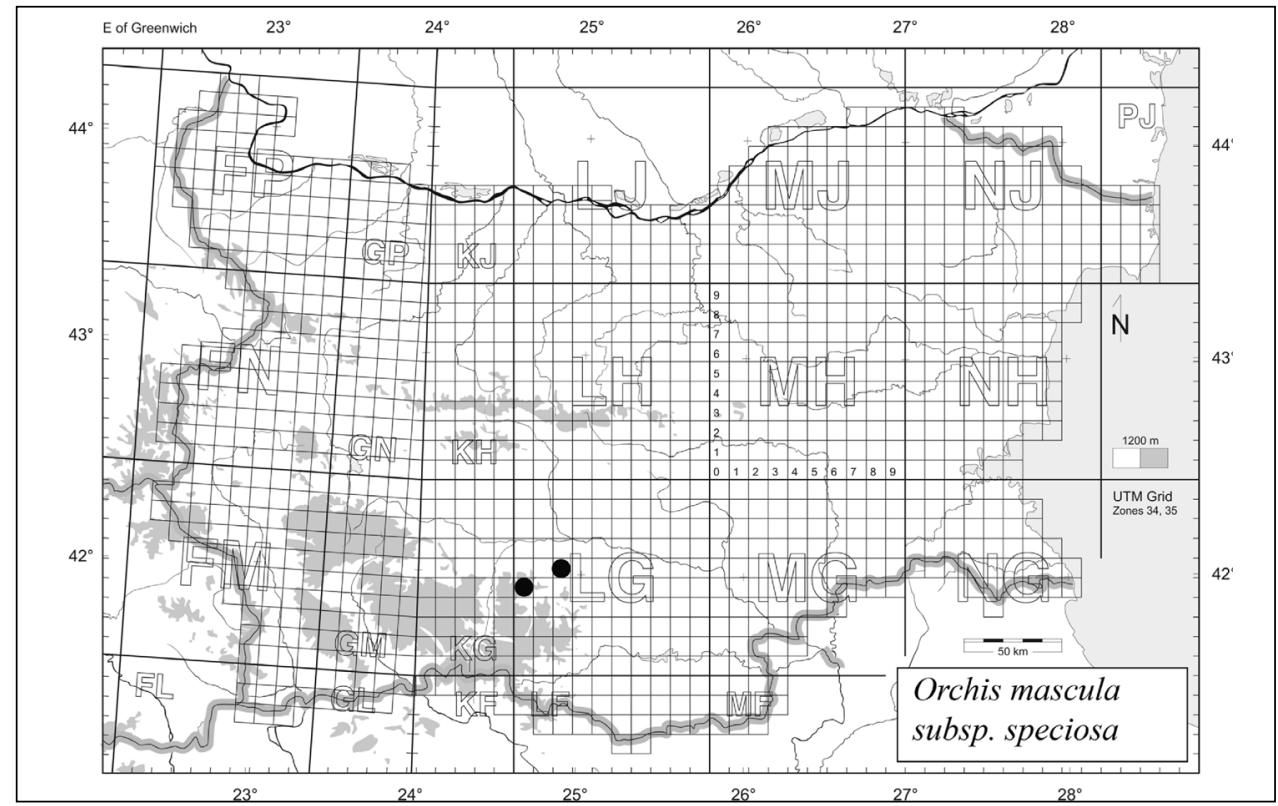

Fig. 12. Distribution of Orchis mascula subsp. speciosa (Mutel) Hegi (= O. ovalis F.W. Schmidt ).

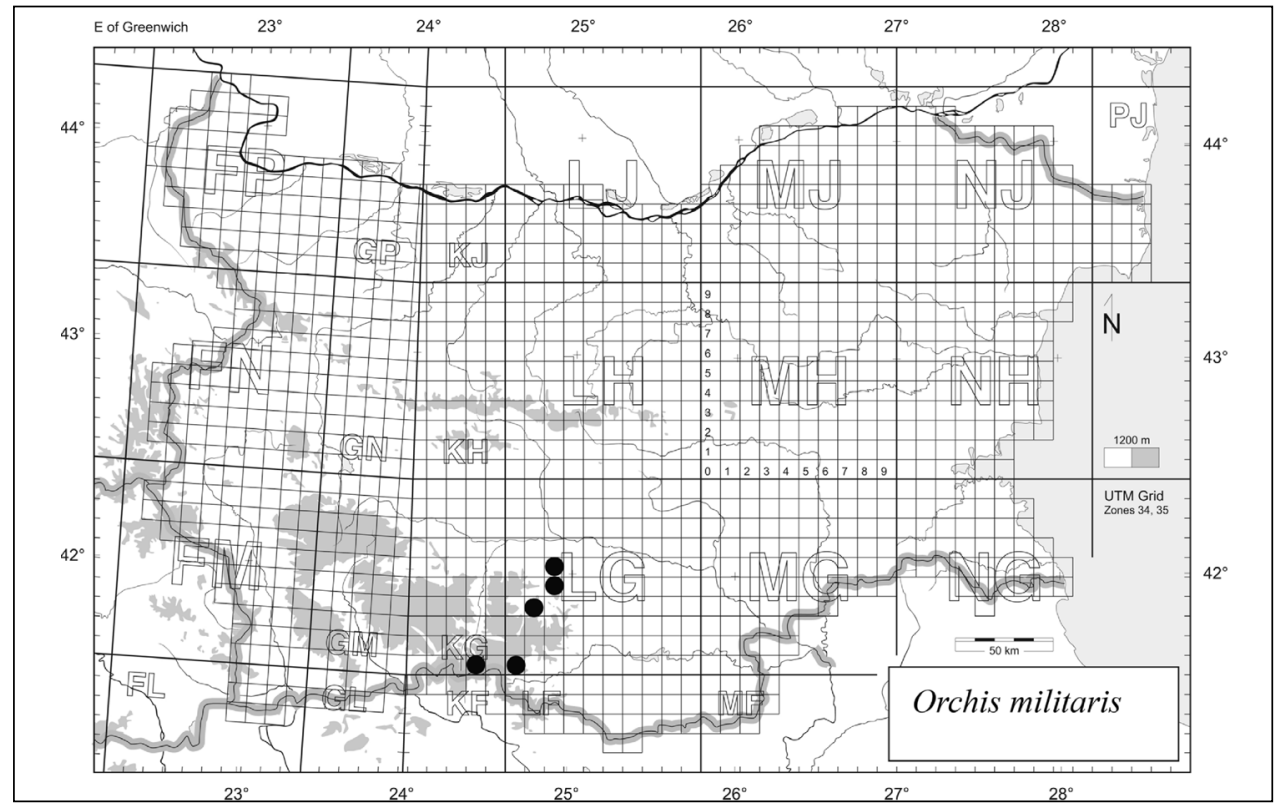

Fig. 13. Distribution of Orchis militaris L. 


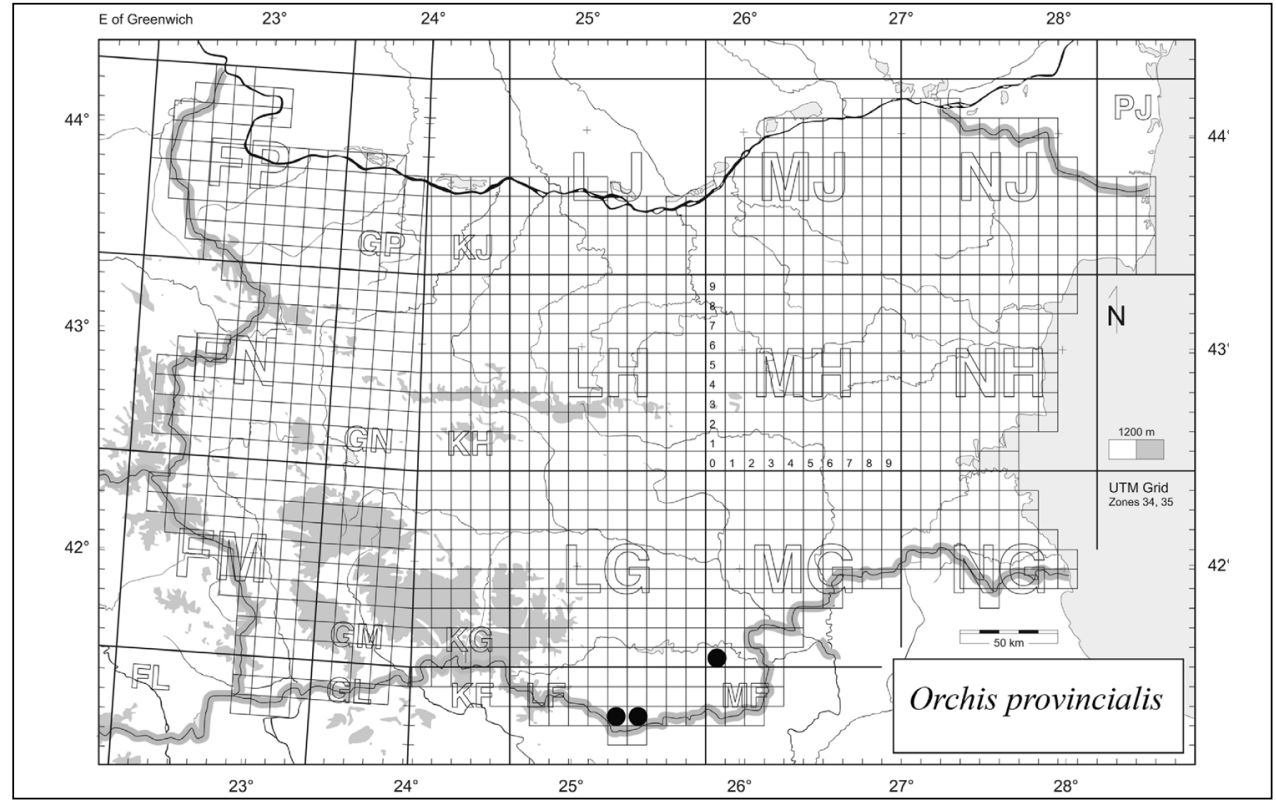

Fig. 14. Distribution of Orchis provincialis Lam. \& DC.

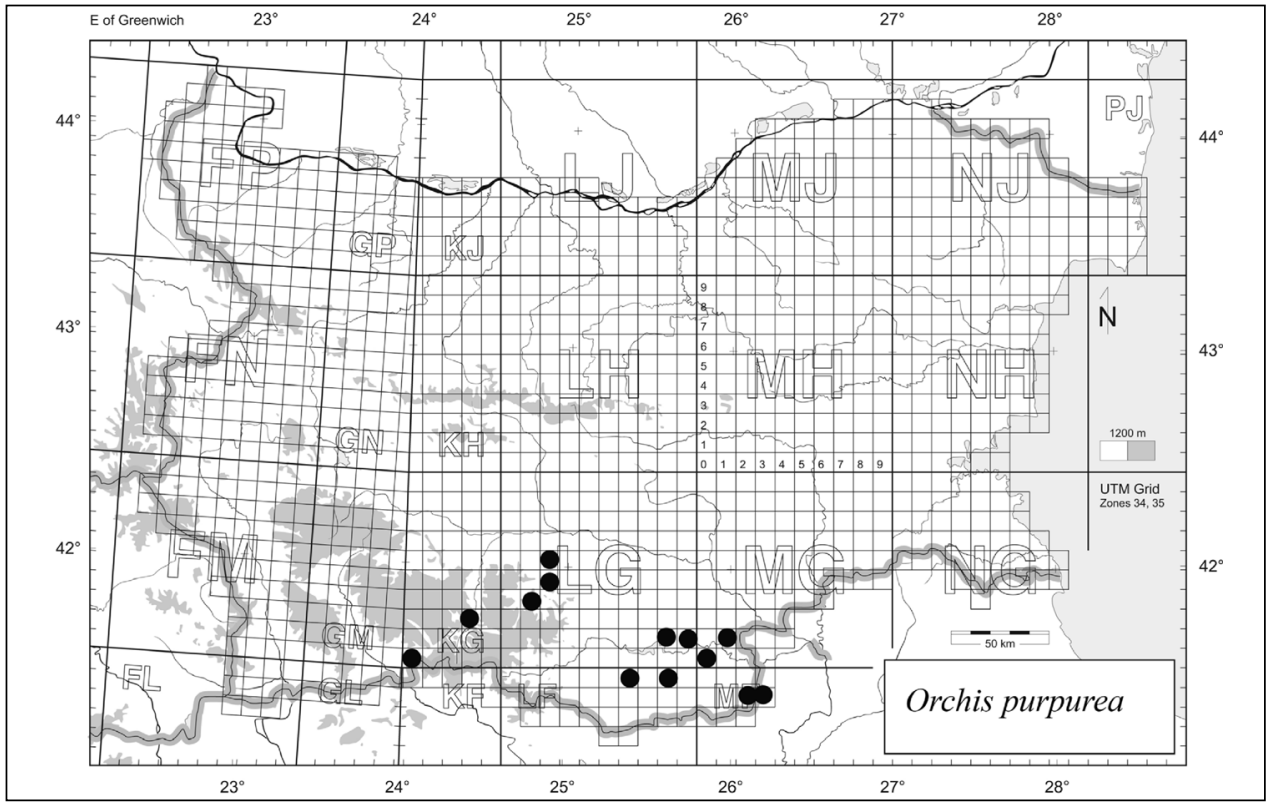

Fig. 15. Distribution of Orchis purpurea Huds. 


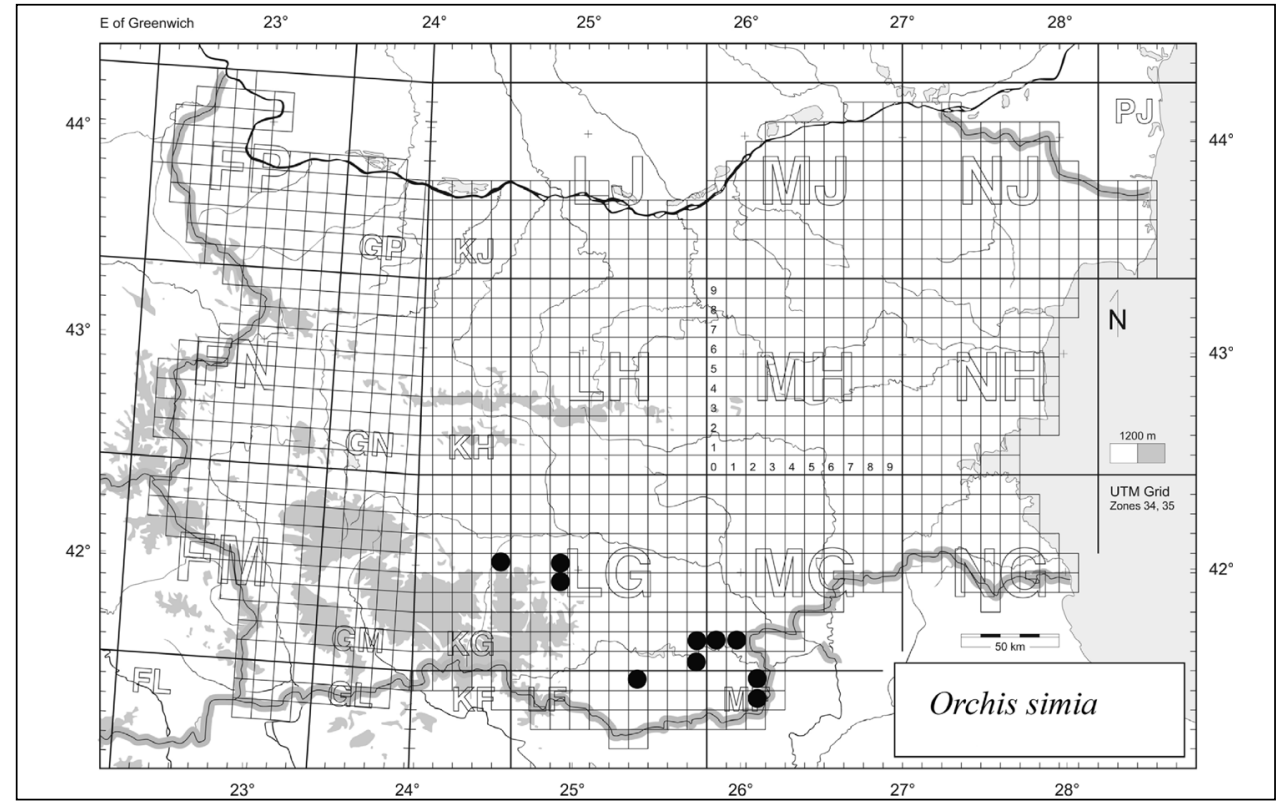

Fig. 16. Distribution of Orchis simia Lam.

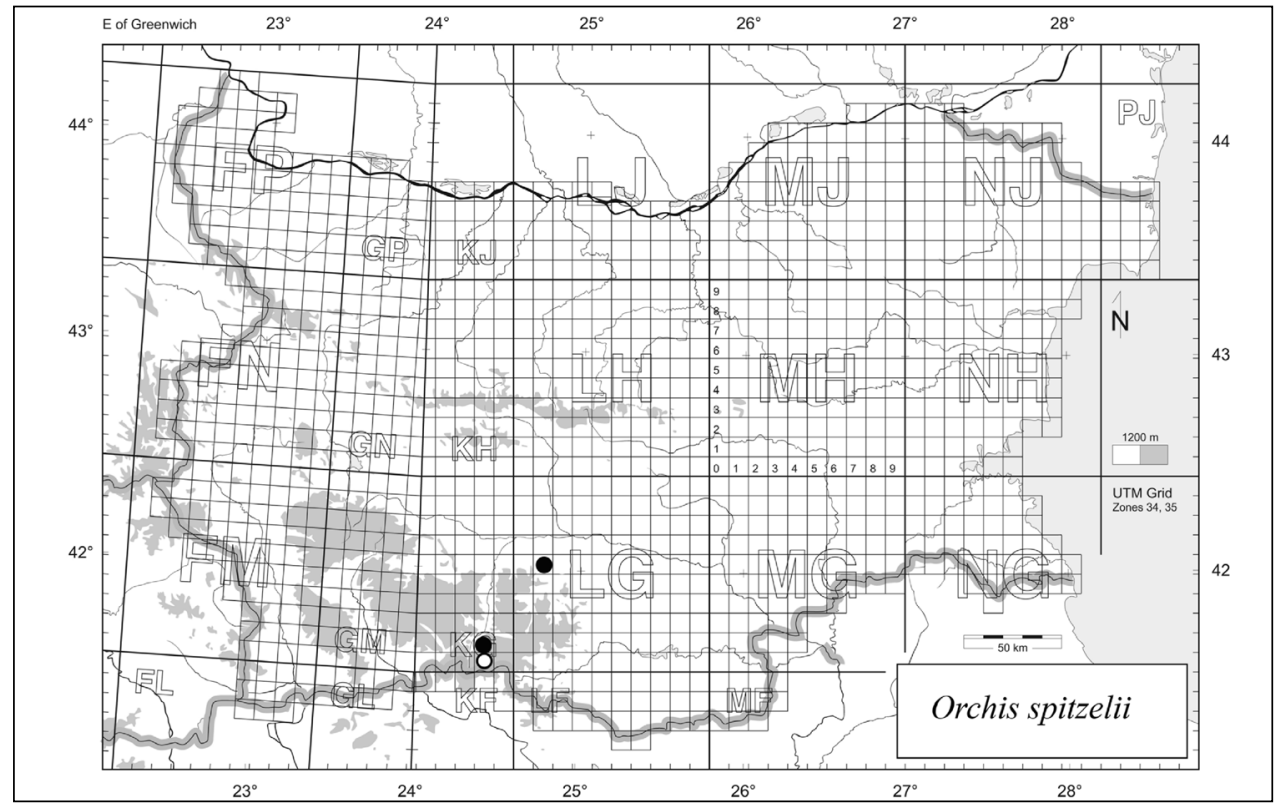

Fig. 17. Distribution of Orchis spitzelii W.D.J. Koch. Note: $\bigcirc-$ population possibly destroyed by development activity. 


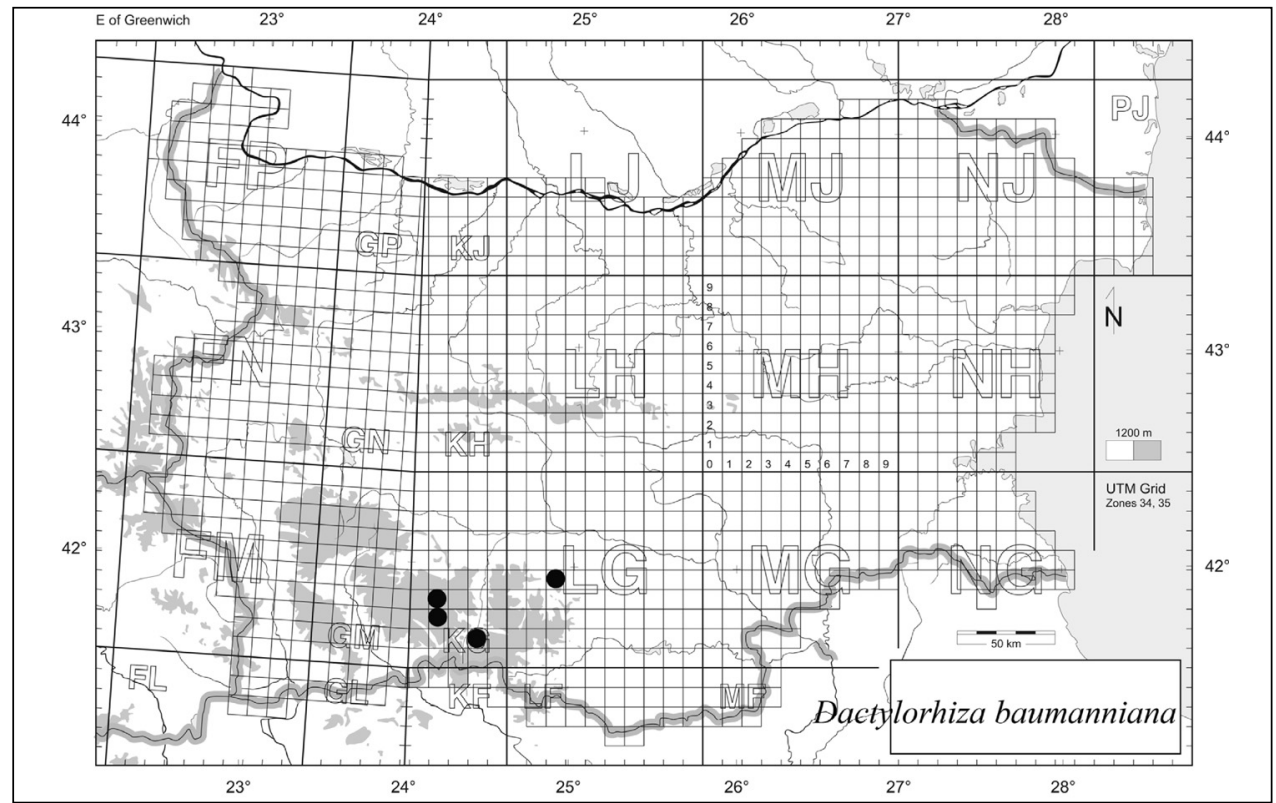

Fig. 18. Distribution of Dactylorhiza baumanniana J. Hölzinger \& Künkele.

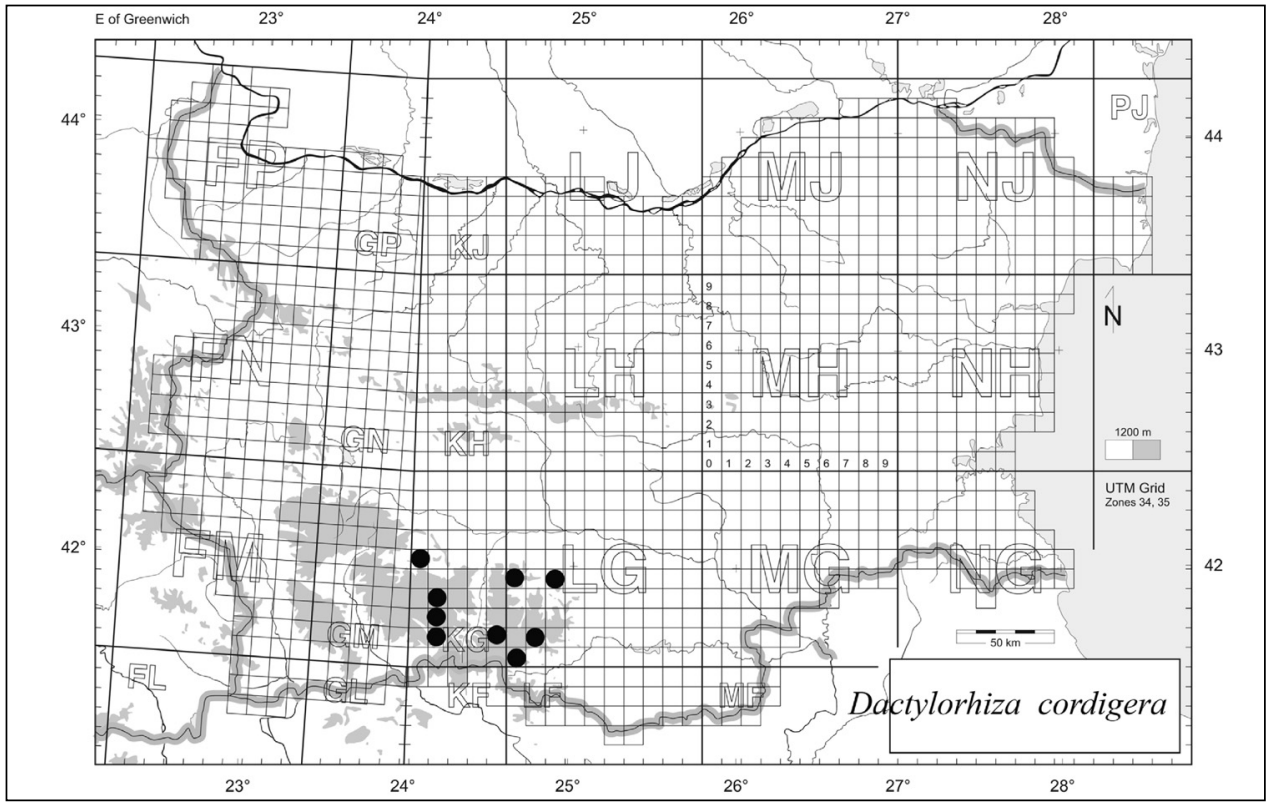

Fig. 19. Distribution of Dactylorhiza cordigera (Fr.) Soó. 


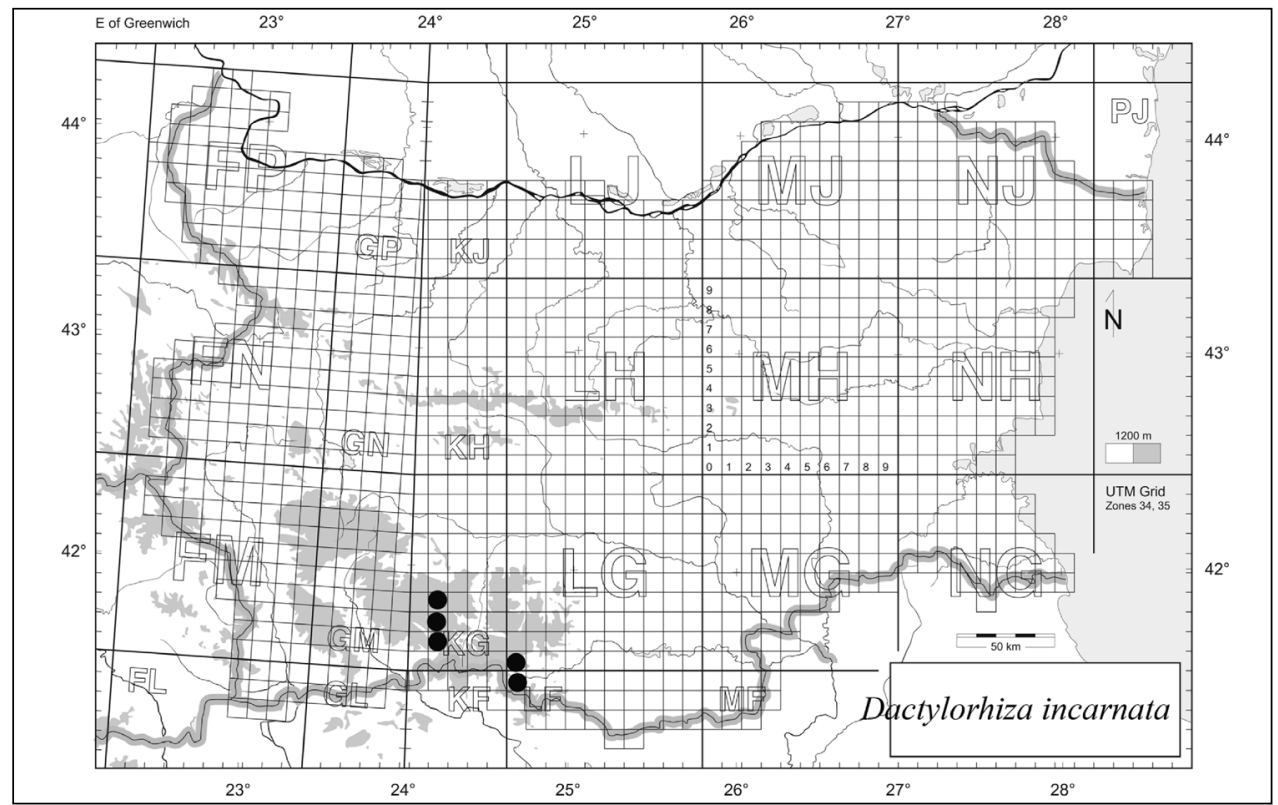

Fig. 20. Distribution of Dactylorhiza incarnata (L.) Soó.

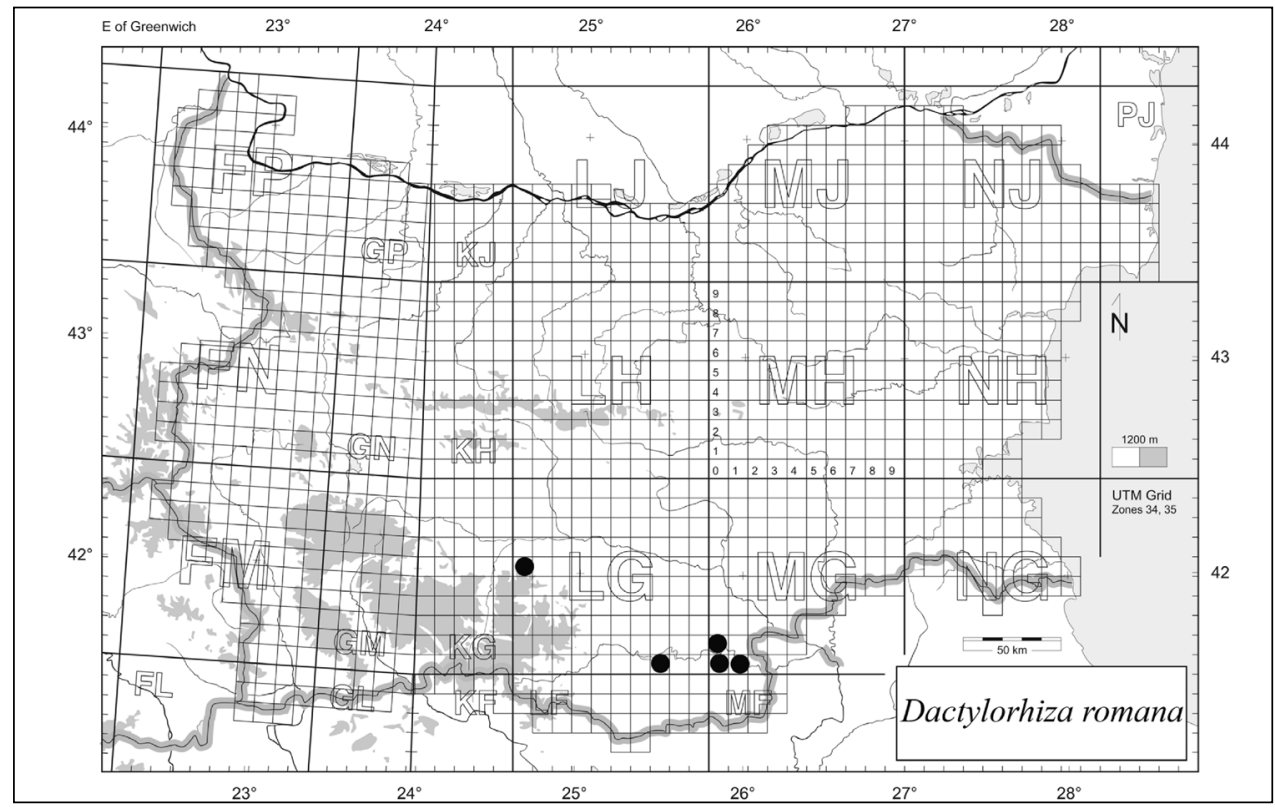

Fig. 21. Distribution of Dactylorhiza romana (Sebast.) Soó. 


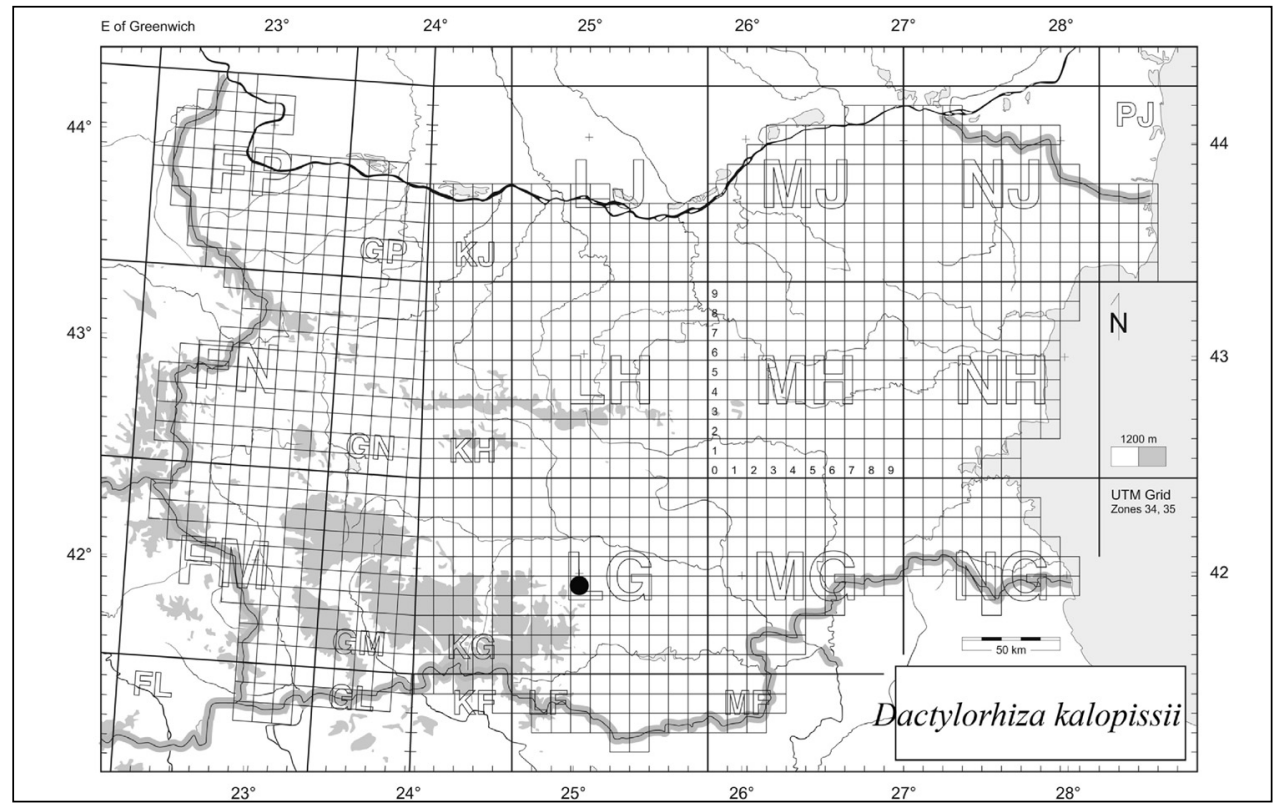

Fig. 22. Distribution of Dactylorhiza kalopissii E. Nelson.

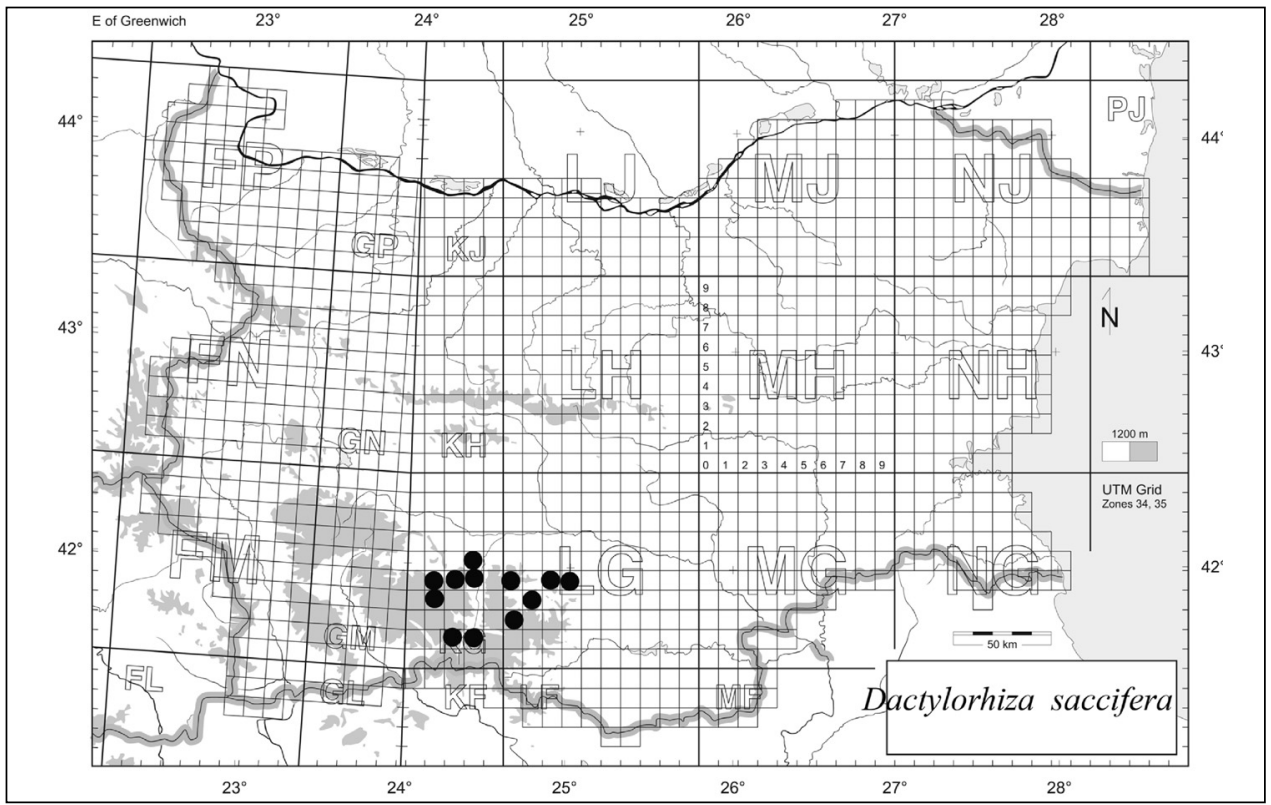

Fig. 23. Distribution of Dactylorhiza saccifera (Brongn.) Soó. 


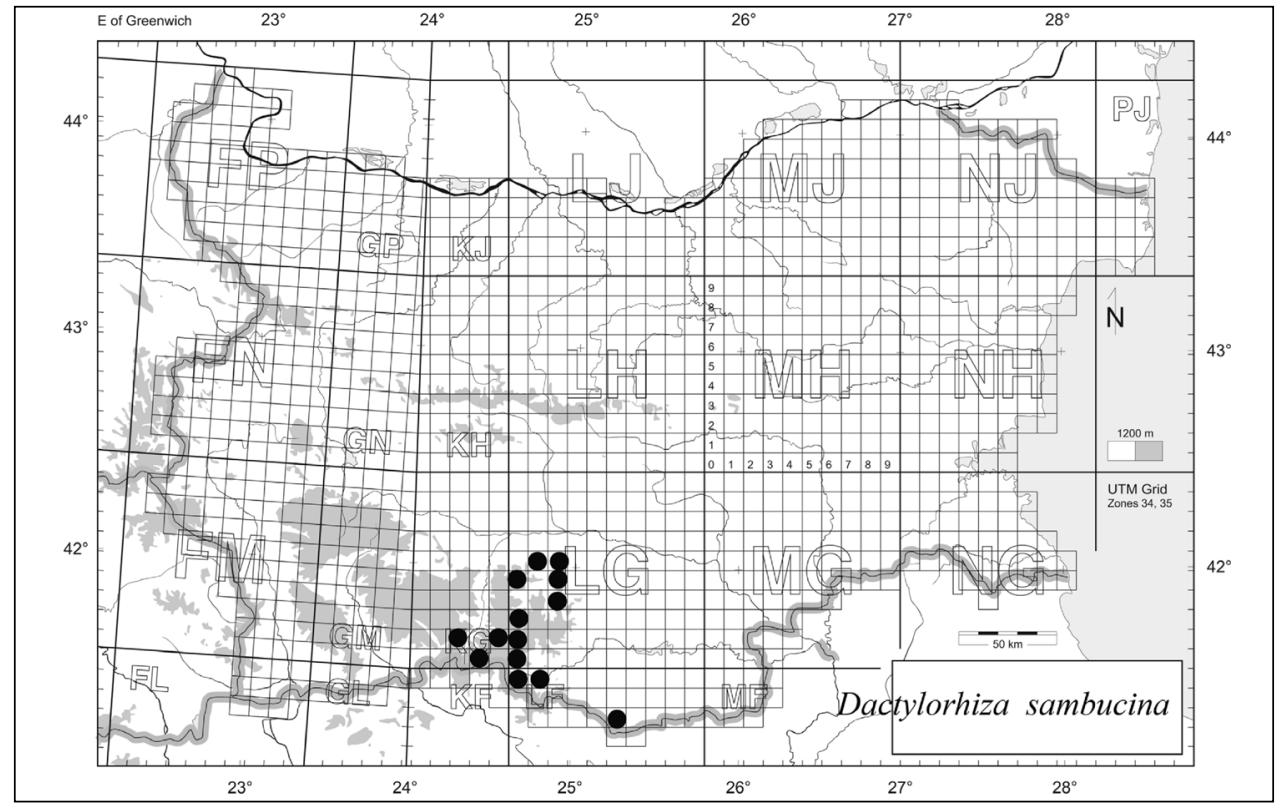

Fig. 24. Distribution of Dactylorhiza sambucina (L.) Soó.

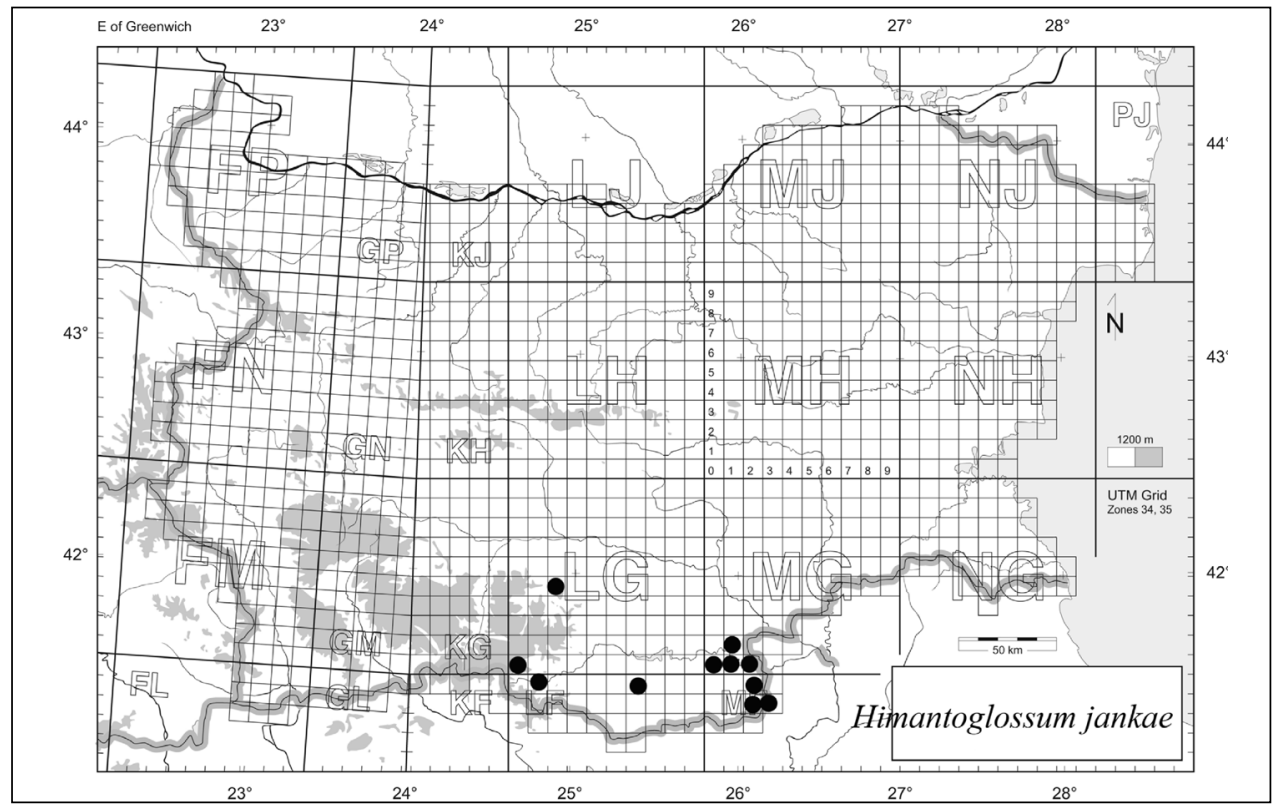

Fig. 25. Distribution of Himantoglossum jankae Somlyay, Kreutz \& Óvári (= H. caprinum auct. pl., non (M. Bieb.) Spreng.). 


\section{References}

Akbulut, S. \& Bayramoglu, M. M. 2013: The Trade and Use of Some Medical and Aromatic Herbs in Turkey. - Ethno. Med. 7(2): 67-77.

Ari, E., Polat, I., Gocmen, M., Karaguzel, O. \& Onal, K. 2005: Phylogenetic Relationship of Turkish Terrestrial Orchids. -Acta Hort. 673: 155-160.

Assyov, B., Petrova, A., Dimitrov, D. \& Vassilev, R. 2012: Conspectus of the Bulgarian Vascular Flora, $4^{\text {th }}$ ed. - Sofia.

Biological Diversity Act Promulgated, State Gazette No. 77/9.08.2002 and Annex 3 to Article 37 (Amended and supplemented, SG No. 88/2005, amended SG No. 94/2007, SG No. 33/2011, effective 27.05.2011)

De Boer, H. J., Ghorbani, A., Manzanilla, V., Raclariu, A. C., Kreziou, A., Ounjai, S., Osathanunkul, M. \& Gravendeel, B. 2017: DNA metabarcoding of orchid-derived products reveals widespread illegal orchid trade. - Proc. R. Soc. B, 284(1863): 20171182. doi: 10.1098/rspb.2017.1182.

Ertug, F. 2004. Wild Edible Plants of the Bodrum Area (Mugla, Turkey). - Turk. J. Bot. 28: 161-174

Euro+Med (2006-2017): Euro+Med PlantBase - the information resource for Euro-Mediterranean plant diversity. Published on the Internet http://ww2.bgbm.org/EuroPlusMed/ [Last Accessed 2 July 2017].

Gerasimova, I., Petrova, A., Venkova, D. 1998: Ophrys apifera Hudson reestablished in the Bulgarian flora. - Phytol. Balcan. 4(3): 53-55.

—, - - - 2003: Distribution of Orchis papilionacea L., Orchis purpurea Hudson and Orchis simia Lam. in Bulgaria. - Ann. Sofia Univ. "St. Kliment Ohridski”, Biol. Fac., 94(4): 84-92.

Ghorbani, A., Zarre, S., Gravendeel, B., de Boer, H. J. 2014a: Illegal wild collection and international trade of CITES-listed terrestrial orchid tubers in Iran. - TRAFFIC Bull. 26(2): 52-58.

-, Gravendeel, B., Naghibi, F. \& de Boer, H. 2014b: Wild orchid tuber collection in Iran: a wake-up call for conservation. - Biodiv. Conserv. 23(11): 2749-2760. doi: 10.1007/s10531-014-0746-y

Hardalova, R., Evstatieva, L. \& Gussev, Ch. 1994: Wild medicinal plant resources in Bulgaria and recommendations for their long-term development. - Pp. 526-561 in: Meine, C. (ed.), Bulgaria's Biological Diversity: Conservation Status and Needs Assessment. -Sofia.

Kasparek, M. \& Grimm, U. 1999: European trade in Turkish "salep" with special reference to Germany! - Econ. Bot. 53(4): 396-406.

Kreziou, A., de Boer, H., Gravendeel, B. 2016: Harvesting of "salep" orchids in north-western Greece continues to threaten natural populations. - Oryx 50(3): 393-396. doi: 10.1017/S0030605315000265

Medicinal plant Act Promulgated, State Gazette No. 29/7.04.2000.

Mitrev, A., Gavrilov, M. \& Tsankov, Ts. 1978: Mapping of the wild medicinal plants in Bulgaria and problems in their processing. - Pp. 1-7 in: Proceedings of the Scientific-practical Conference on Phytochemistry, Phytochemical Productions and Phytotherapy. - Sofia. (In Bulgarian).

Molnár V. A., Nagy, T., Löki, V., Süveges, K., Takács, A., Bódis, J. \& Tökölyi, J. 2017: Turkish graveyards as refuges for orchids against tuber harvest. - Ecol. Evol. 7(24): 11257-11264. doi: $10.1002 /$ ece 3.3562

Petrova A. 2004: Flora of the Eastern Rhodopes (Bulgaria) and its conservation significance.). - Pp. 53-118 in: Beron, P. \& Popov, A. (eds), Biodiversity of Bulgaria, 2. Biodiversity of Eastern Rhodopes (Bulgaria and Greece). - Sofia.

-, Venkova D. \& Sopotlieva D. 2006: Contribution to the flora of the Rhodopes and the Thracian plain. - Hist. Nat. Bulgarica 17: 27-33.

— \& Vladimirov, V. (eds) 2009: Red List of Bulgarian vascular plants. - Phytol. Balcan. 15(1): 63-94. 
-, Assyov, B. 2008: Reports 55-62. - In Vladimirov, V., Dane, F. \& Tan, K. (eds), New floristic records in the Balkans: 9. - Phytol. Balcan. 14: 440-442.

-, Gerasimova, I., Venkova, D. 2001: Orchids in the protected areas "Dupkata" and "Likana" in Eastern Rhodopes. - Pp 434-439 in: Proceedings Third Balkan scientific Conference, Third Balkan scientific Conference Study, conservation and utilization of forest resoures. Sofia, 2-6 Oct. 2001, 2. - Sofia.

Sezik, E. 2002: Turkish Orchids and Salep. - Acta Pharm. Turcica 44: 151-157.

Stojanov, N. 1964: Orchidaceae - Pp. 349-399 in: Jordanov, D. (ed.), Fl. Reipubl. Popularis Bulgaricae, 2. - Sofia. (in Bulgarian).

Stojanov, N. \& Kitanov, B. 1960. Wild useful plants in Bulgaria. - Sofia. (in Bulgarian).

Tamer, C. E., Karaman, B. \& Copur, O. 2006: A Traditional Turkish Beverage: Salep. - Food Rev. Intern. 22(1): 43-50.

Tecimen, H. B., Sevgi, O., Kara, E., Sevgi, E., Altundag, E. \& Bolat, I. 2010: The problems of "salep" species of Turkey and solution suggestions. - J. Western Medit. For. Inst. 10(2): 1-30.

Trifonov, V. 2005: State of the population of Orchis provincialis Balbis in the Eastern Rhodopi Mts. - Pp. 161-166 in: Chipev, N. \& Bogoev, V. (eds), Biodiversity, Ecosystems, Global Changes. First National Scientific Conference in Ecology. - Sofia (in Bulgarian).

Vassileva, S. \& Vihodcevsky, N. 1974: Supplement pour la flore des Rhodopes orientales. - God. Sofiisk. Univ. Biol. Fak. 66(2): 41-44 (in Bulgarian).

Yordanova, M. 2016: Orchids of the Rodopi Mountains. - Sofia (in Bulgarian).

Addresses of the authors:

Irena Mincheva ${ }^{1}$, Antoaneta Petrova $^{2}$, Mihaela Yordanova ${ }^{3}$ \& Ekaterina Kozuharova $^{1}$,

${ }^{1}$ Department of Pharmacognosy and Botany, Faculty of Pharmacy, MU-Sofia, Dunav 2 sr. Sofia 1000, Bulgaria. E-mail: ina_kozuharova@yahoo.co.uk

${ }^{2}$ Botanical Garden, Bulgarian Academy of Sciences, P.O. Box 664, 1000 Sofia Bulgaria. E-mail: petrovabotgar1@abv.bg

${ }^{3}$ Nezabravka' Street, No. 25, Room 207 'Iztok' 1113 Sofia Bulgaria. E-mail: info@wildrodopi.org 